\title{
Educator Perspectives on the Social and Academic Integration of Syrian Refugees in Canada
}

\author{
Antoinette Gagné \\ Nadeen Al-Hashimi \\ Michelle Little \\ Morgan Lowen \\ Anoop Sidhu \\ University of Toronto \\ Canada
}

\begin{abstract}
Through a survey and interviews intended as a pilot for a larger study, we explored the perspectives of K-12 educators on the social and academic integration of refugees. The thematic analysis of the data reveals the complex and intersecting factors that impact their success in schools and the relative ability of Syrian children and youth to bridge the multiple worlds in which they live. The role of educators, peers, and family are highlighted as well as promising programs and practices that support the integration of refugee learners and their movement between different spheres.
\end{abstract}

Keywords: Syrian refugees, educational integration, relationships 
Educator Perspectives on the Social and Academic Integration of Syrian Refugees

\section{Introduction}

The arrival of more than 50,000 Syrian refugees in just over 2 years has created critical opportunities and challenges for Canadian schools, which are at the forefront of educational policies and programs designed to ensure the successful integration of these newcomers. In spite of intensive efforts to ensure the educational integration of refugees across Canada, there remain challenges and issues to address. Our research considers the integration of the various waves of Syrian refugees over the past 3 years from a standpoint of complex, nuanced, and intersecting factors that impact their success in schools. Educator experiences as well as promising programs and practices that support the social and academic integration of refugee children and youth at different stages and across various contexts have been documented.

\section{Overview of Article}

An overview of the education policy context impacting the integration of refugees in Ontario schools is presented, a review of the literature on the experiences of refugees in Canadian schools and communities is provided, followed by a description of our conceptual framework, the Bridging Multiple Worlds theory (Cooper, 2014). Short descriptions of several schools that have welcomed Syrian refugees provide a sense of the diverse school settings where data was collected. Then, we use our conceptual lens to highlight the role of relationships and programs in the integration of Syrian children and youth. We end with some suggestions of promising practices that emerge from our initial findings.

\section{Education Policy Context}

As the Canadian government stopped posting updates on the number of Syrian refugees resettled in Canada as of January 2017 (Government of Canada, 2017), we have drawn on statistics provided in an article from a large Toronto newspaper stating that 48,400 Syrian refugees arrived in Canada between November 2015 and July 2017, including 25,000 in the government-assisted category; 19,000 in the privately-sponsored category; and 4,400 who were jointly sponsored. In addition, another 21,000 applications are reported as "in process" as of July $2017-5,000$ of these are government supported and 16,000 are privately sponsored (The Star, September 25, 2017).

The Ontario Ministry of Education shares a collaborative relationship with both the federal government and multiple school boards to ensure that Syrian refugees are welcomed with adequate resources and effective support systems, in relation to aspects such as mental health and language development (Ontario Ministry of Education, 2015). Key areas of development that continue to require specific attention and to which community resources, ministries, and stakeholders are contributing include: health initiatives, funding for programs and resources such as translators, settlement and housing placements, language/literacy programming and supports, as well as religious accommodations (Ontario Ministry of Education, 2016).

In order to address the need for effective language development programs, the Ministry has initiated the STEP program that essentially organizes and provides a platform for classroom and resource teachers to monitor and assess student progress and plan next steps, as well as the English as a Second Language (ESL) programming (Ontario Ministry of Education, 2016). Moreover, it is used to place students in appropriate classes and grade levels to maximize their learning supports, while ensuring they have multiple opportunities to interact and communicate with peers of their own age (Ontario Ministry of Education, 2016). 
With the support of community agencies such as School Mental Health (SMH)

Newcomer Resource Group, school boards now have access to mental health professionals who can provide guidance and strategies when working with immigrants and refugee students (Ontario Ministry of Education, 2016). A statement from a 2015 document promises that "the Ministry, in partnership with the federal government, will ensure that school boards have the resources and support required to successfully integrate Syrian refugees into our education system" (Ontario Ministry of Education, 2015, p.3).

Ontario's policy for English language learners (ELLs) highlights the importance of the academic and social integration of students with limited literacy skills (MEO, 2008). As such, a vision statement (MEO, 2015) describing the learning conditions essential for success of such learners was released and asserts that ELLs will:

- learn English at the same time as they are learning the content of the Ontario curriculum

- $\quad$ see themselves in the learning environment

- feel that their culture and language are valued

- have confidence to express their opinions and know they have a voice

- meet high expectations when they are involved in setting goals

- have opportunities to choose pathways that honour their strengths and interests. (p. 8)

\section{Literature Review}

The Toronto School District is a diverse community that is home to multiple cultural backgrounds and languages in which over $50 \%$ of its students communicate in a language other than English (TDSB, n.d.). Other school districts where Syrian refugees have settled in the greater Toronto area are equally diverse. As a result of the Syrian refugee crisis and the massive increase in global migration, there has been a significant demographic shift in the makeup of Canadian classrooms (MacKinnon, 2017). Therefore, the need for educators to modify their pedagogical strategies and approaches and rethink their role(s) and the nature of the relationships between the school, families, and communities is greater than ever before (Hoot, Szente, \& Taylor, 2006; Sidhu \& Taylor, 2012).

Several studies describe how refugee students' lived experiences and their emotional well-being are connected to their academic performance and social interactions. For instance, as a result of trauma-related experiences and being separated from family members, students often display feelings of mistrust and anger (Allard, 2016; Refugees from Syria, 2014; Roxas, 2011). Parental involvement in relation to the extent to which they are part of the school community, the level of communication between families and teachers, and educator views on their students' negotiation of cultural identities in relation their academic success comprise a large portion of the literature (Chostelidou \& Griva, 2014; Guo, 2012). Several studies conducted with newcomers invite educators to consider how their values and attitudes may impact their practices and how they might work to create a trusting, safe, and inclusive environment for students to learn, including making use of refugee learners' language(s) and culture(s) to inform their English language learning while accessing resources to meet student needs to ensure their social, academic, and emotional integration (Cummins, Markus, \& Montero, 2015; Giampapa, 2012; Hoot et al., 2006; Sergiovanni, 1994; Sidhu \& Taylor, 2012).

Students across various studies identify language barriers as a significant challenge. Study participants expressed fear of being ridiculed in social interactions, anxiety related to using appropriate vocabulary, and a lack of confidence with respect to reading fluency and writing 
sophistication (Chostelidou \& Griva, 2014; Minichiello, 2001). Examples of established education programs designed to support ELLs outlined in the Supporting Students with Refugee Backgrounds (2016) include the English as a Second Language (ESL) program and the English Literacy Development (ELD) program, which differ in nature and purpose. While the ESL program encompasses students who have had prior learning experiences and thus are at grade level with respect to their first language, the ELD program is a much more intensive program that aims to work with students who have had very limited to no literacy/language opportunities in their native tongue, which is the case for many Syrian children who have spent several years out of school. Often in ELD programs, students are segregated from their mainstream peers for a large portion of the day, in hopes of working on their language development and to accelerate their learning (Cummins, 2015).

Hence, the literature thoroughly examines multiple dimensions of the complex experiences of Syrian Refugees in relation to language barriers, emotional instability, social relationships, the role of parents, administration, teacher attitudes, access to resources which all in turn shape their multiple identities and experiences as learners in Canadian schools.

\section{Our Theoretical Framework: Bridging Multiple Worlds Theory}

An important lens thourgh which to understand our findings is the Bridging Multiple Worlds (BMW) theory (Cooper, 2014), which focuses on the development of the child living across the worlds of home, school, and community. This theory helps us to understand how children and youth continually navigate between the worlds of peers, school, home, as well as religious and cultural activities, sports, and other extracurricular programming, each of which has different expectations and goals.

The BMW lens extends Bronfenbrenner's Ecological Systems theory (Bronfenbrenner, 1979) with a focus on how minority children and youth navigate the different spheres of their lives including home, school, and community. This theory understands child development as taking place in nested systems with the microsystem including family, school, and peers at the center and the mesosystem, exosystem, and macrosystem revealing many layers of conditions influencing the development of the individual. The chronosystem highlights the temporal aspects of development and how different factors may impact development more or less depending on age and history.

In the Bridging Multiple Worlds theory, the educators, peers and family members that children and youth interact with are understood as mediators who fall somewhere on a continuum between brokers who support students in overcoming challenges and gatekeepers who create barriers for the educational integration or success of students. Thus, supportive relationships and access to resources are viewed as the necessary conditions to help students overcome barriers to success such as their status as refugees, poverty, racism, Islamophobia, and so on (Cooper, 1994). Furthermore, the BMW model suggests that when appropriate supports and challenges are aligned, students will experience greater success in terms of their academic and social integration and their ability to navigate between their multiple worlds. Cooper (2014) explains that bridging processes involve the coordination of assets and resources to ensure that these are aligned with the challenges faced by children and youth.

We have adapted Cooper's (2014) Bridging Multiple Worlds model to help us better understand the education integration of Syrian children and youth. 


\section{Bridging Multiple Worlds Theory}

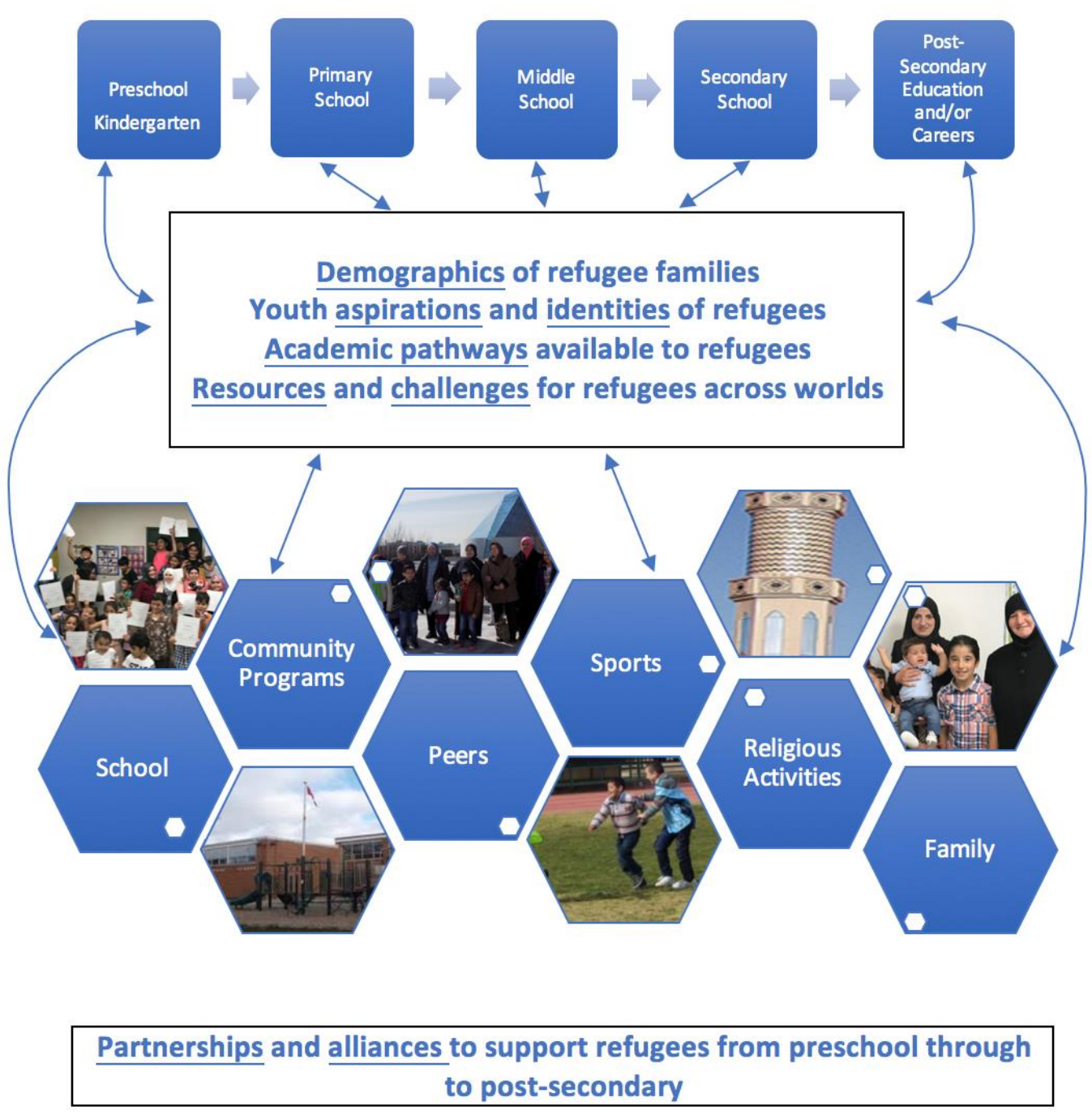

Figure 1. Bridging Multiple Worlds - Syrian Refugee Children and Youth in Ontario (Adapted from Cooper, 2014)

Our study focuses on the educational integration of Syrian children and youth in the microsystem which includes school, peers, family, and community (Bronfenbrenner \& Morris, 2006). More specifically, this study provides educator perspectives about how refugee students experience navigating across these developmental contexts. Cooper's (2014) BMW model frames this study in exploring how children and youth access brokers as resources to overcome the challenges of navigating multiple worlds and sometimes encounter gatekeepers that slow their integration.

Although various factors may affect the social and academic integration of refugee students, in this article we focus on the relationships developed by Syrian children and youth and consider how they may impact on their educational integration. Our pilot study helps us to understand that various aspects of the identity of Syrian refugee students affect their social and 
Educator Perspectives on the Social and Academic Integration of Syrian Refugees

academic integration including the nature of their sponsorship, their housing situation, the size of their immediate family, their age, their proficiency in English, the nature of their journey to Canada, their parents' SES in Syria before the war and more. In addition, other factors beyond the individual refugee learner emerge as influential in their integration including: 1) the preparedness of the teachers and the school, 2) the number of refugees enrolled in a particular school, 3) the nature of the neighbourhood surrounding the school, 4) the number of supports in place at school and in the community and 5) access to English speakers.

\section{Methodology}

The findings presented in this article are part of a pilot for a larger study that includes a survey and an embedded case study. The survey, to be distributed widely in Canada and Europe, will provide a wide-angle lens on the social and academic integration experiences from the viewpoint of educators across countries. The embedded case study, which is currently in its early stages includes schools in the Toronto School District and the Peel School District, where a large number of refugees attend school as well as non-government organizations in the Greater Toronto Area including: Syrian Active Volunteers (SAV) Canada, and the Afghan Women's Organization (AWO). The embedded case study draws data from multiple sources including: 1) the multimedia artifacts emerging from "me mapping" or identity-focused activities designed for children and youth to share their experiences in Canadian schools as well as other aspects of their lives before and after arriving in Canada, 2) focus groups with Syrian children and youth, 3) focus groups with parents of Syrian children and youth, as well as 4) interviews and focus groups with educators including settlement workers.

The findings presented in this article include responses from 15 interviews with educators and 25 completed surveys. Major themes addressed in both the survey and the interviews with educators include: demographics and characteristics of the Syrian refugee populations, the nature of relationships between Syrian students, their peers, teachers and families, as well as particular programming and practices for Syrian youth and factors affecting their integration. The survey responses and interview data are integrated in the presentation of findings.

\section{Description of Research Team}

Our research team was comprised of several graduate students enrolled in different programs across OISE, including the Master of Teaching (MT) that affords school placements with observation, teaching, and other opportunities to interact with teachers and learners. The lead author Antoinette Gagné is a professor, researcher. and course director for the Supporting English Language Learners required course in the MT program. Morgan Lowen and Anoop Sidhu are graduate students preparing to teach in elementary schools, while Nadeen Al-Hashimi and Michelle Little are preparing to teach in secondary schools. Their placements have brought them into schools across the greater Toronto area and, in particular, into certain neighborhoods where Syrian families have settled. Each member of the team conducted two or more interviews with educators and promoted the survey amongst their colleagues in schools. They also did some of the initial coding of selected interviews. 
Antoinette Gagné et al.

\section{Diverse Schools}

Teachers in our pilot study described their schools, and we have included a brief portrait of four schools to give a sense of the very diverse environments where Syrian children and youth are attending school.

\section{Urban Elementary School}

Urban Elementary is a Kindergarten to Grade 6 school with a population of 150 Syrian children among its total school population of 700 children from working-class as well as firstand second-generation immigrant families. Most of the children live in the neighbouring apartment buildings and the refugee families have for the most part been sponsored by the government to come to live in Canada. There is a mixture of families who either identify as Kurdish or Syrian. Most of the children are from large families who lived in refugee camps for a few years and, as such, they have experienced gaps in their education. These children are supported by two full-time ESL teachers as well as one part-time settlement worker. However, the children from Syria are also assigned to mainstream classrooms for part of the day with teachers who have not received any specific training to work with refugee children dealing with trauma. Most teachers report feeling seriously unprepared and under supported in their work with refugee children.

One ESL teacher at Urban Elementary works primarily with children in Grades 1 to 3 and another with children in Grades 4 to 6 . Each educator teaches intensive math and language to mostly newcomer students who are not at grade level. They also provide ESL support across several classrooms for students who are at grade level for math content, but still behind in language. Each ESL teacher works with a dozen students, most of whom are refugees, and they provide intensive Math and English support. The ESL teachers' rooms are set up such that the teacher can easily conference with the students as they work independently or in small groups. Both of the experienced ESL teachers find it unsettling to hear so much Arabic spoken in their classrooms, especially when they observe their students involved in heated debates which they cannot understand. The teachers worry about what the children might be saying about each other or their families, as there have been ongoing tensions between the Kurdish and Syrian students. They also feel that the Syrian children would benefit more from their time at school if they took up the opportunity to speak English more frequently. In fact, the teachers often engage the students in storytelling activities to allow them to share as much as they want about their lives.

\section{Rural Elementary School}

Rural Elementary is one of several rural schools that each welcomed a few Syrian families who were privately sponsored by local churches practicing a "minority" religion. The support provided by the private sponsors varied, and the integration of the Syrian families into the local community was not observed, as the religious beliefs and practices of the hosts and the newcomers were significantly different. The majority of the refugee children experienced a 4year interruption to their education. Only a couple of families were able to afford private school fees for their children when they fled to Lebanon.

An itinerant ESL teacher is assigned a number of refugee children to support across several rural schools in this large district. This means that the ESL teacher may only spend part of a day at Rural Elementary every week because they may have to visit another school the same day. The roles of itinerant ESL teachers include conducting initial assessments of math and language skills, creating awareness of the potential challenges faced by the refugee students as they adjust to their new environment, providing advice and support to classroom and specialist 
Educator Perspectives on the Social and Academic Integration of Syrian Refugees

teachers across several schools as well as developing inclusive curriculum resources. To respond the literacy needs of the refugee students, a summer camp was organized centrally. In addition, a child youth counsellor was assigned to work with these children. However, as the counsellor does not speak Arabic, there was not as much interaction with the children as the teachers felt was needed. Although itinerant teachers have encouraged schools to bring in interpreters to facilitate working with families, most rural school administrators do not seem open to this.

\section{Urban Secondary School}

Urban Secondary is an inner-city Toronto high school with over 1500 students, located in a neighbourhood which is home to one of the highest concentrations of immigrants from various parts of the world. In addition to a large ESL program with credit courses in English Literacy Development (ELD) for students who need to accelerate their literacy skills, there are credit ESL courses provided at five levels as well as ESL-sensitive courses for newcomers available in geography, history, business, math, and science. There is also an art therapist and a non-Arabicspeaking part-time settlement worker supporting the needs of Syrian teens. In addition, Urban Secondary is home to an enrichment program for students who excel in and share a strong interest in mathematics and science as well as other programs focussing on various professions with opportunities for placements in diverse workplaces.

There are several sections of ELD classes with up to 15 students mostly from Syria. The students range in age from 14 to 20 and have for the most part experienced 4 years of interruption to their formal education. Some of the students could not afford to attend school because they worked after fleeing Syria in an attempt to help support their large families. The ELD teachers are often overwhelmed when planning for the multiple social and academic needs of their 15 or so students who each have different knowledge gaps and roles to play within their families. Planning and delivering engaging and meaningful lessons to such diverse learners with a large spectrum in their education gaps has proven extremely challenging, to the point where teaching assistants and peer tutors have been recruited to work alongside the teacher in every class. When lessons focus on a concept that may not be familiar to all students, some students tune out and begin to behave disruptively. An example of this occurred when the ESL teacher prepared a lesson related to the cardinal points assuming that her refugee students would be familiar with this concept. However, during this lesson, one student became so agitated that the teacher felt she needed to resort to send him to the principal's office. This student had never learned about cardinal points and needed one-on-one support to be able to learn this important concept and get over his embarrassment.

\section{Suburban Secondary School}

Suburban Secondary is a designated hub for English learners located in a city bordering on Toronto, and a bus service is provided for students who live at a significant distance from the school. It is home to a very diverse group of about 800 students from around the world. Recently, Suburban Secondary has welcomed more than 100 Syrian refugee from age 14 to 20. Suburban Secondary is located in a densely populated neighbourhood with many low-cost high rise buildings, shops, and services. In fact, there are several NGOs that offer a range of supports and services for the many Syrian families who have recently settled in the area. A number of the families lived in motels or hotels for several months after their arrival as they waited for suitable accommodation. 
The school offers a full range of English as Second Language (ESL) courses designed for language learners who have had opportunities to develop language and literacy skills in their own language appropriate to their age or grade level as well as English Literary Development (ELD) courses designed for English learners with limited prior schooling who have not had opportunities to develop age-appropriate literacy skills in any language. These courses provide an accelerated program of literacy development for these students. There are also ESL-sensitive courses in some disciplines, including general science and mathematics as well as a special cohort for 18-to-21 year olds who have experienced interruptions in their education and need an accelerated pathway to post-secondary education or the workplace. Although there are settlement and youth workers attached to Suburban Secondary, they do not all speak Arabic. As such volunteer teaching aides and peer-tutors with a knowledge of Arabic are much sought after.

Teachers at Suburban Secondary report the steady progress made by some of the Syrian teens who have attended the school for two years. During their first year at the school, students tended to remain in their groups, while teachers observed much higher levels of community involvement in the second year. Several of the Syrian students at Suburban Secondary complain that it is difficult for them to learn English as they do not have sufficient opportunities to use their new language due to the high number of Arabic-speaking students attending their school and the high density of Syrian families living in the neighbourhood surrounding the school. The educators report that their greatest challenge is working with older students who are returning to a formal school environment after years of interruptions. Their need for these students to learn how to learn is a formal context with attendance, communication and homework expectations is part of the teaching job that they report they were not prepared for.

\section{Research Participants}

Twelve of the 15 educators interviewed are either elementary or secondary school teachers, while three identified as principal, vice-principal, and settlement worker. The educators who completed the survey are from nine school districts in southern Ontario including public and Catholic districts as well as from 22 distinct institutions. Seventy-seven percent of respondents reported working in elementary or middle schools (Kindergarten up to Grade 8). Twenty-seven percent reported working with more than 15 Syrians students, $34 \%$ with 5 to 15 Syrian students and $36 \%$ between 1 and 5 Syrian students. Thirty percent of educators reported that some of the Syrians in their schools are government sponsored, another 30\% report that their Syrian students are privately sponsored while $40 \%$ of respondents are not aware of the nature of sponsorship of their students.

\section{English Proficiency Development of Syrian Children and Youth}

Before digging into the findings it is important to note educators' perspectives on the English proficiency development of the Syrian refugees with whom they work. In fact, $82 \%$ of respondents report that the Syrian students in their school have experienced interruptions to their formal schooling. In addition, 59\% of the educators agree or strongly agree with this statement: The Syrian students I work with have made continuous progress in developing their English language skill,s while $38 \%$ of respondents agree or strongly agree that the Syrian students they work with are struggling to learn English. It is not surprising that nearly $40 \%$ of educators say that their students are having difficulties learning English as so many of the Syrian refugees have not been in school for a number of years. 
Educator Perspectives on the Social and Academic Integration of Syrian Refugees

\section{The Role of Relationships in the Integration of Syrian Refugees in Canada}

Although we report on our findings overall, we focus on educator perspectives about how refugee students experience navigating across their multiple worlds (Cooper, 2014) by sometimes accessing brokers as resources to overcome the navigation challenges and at other times encountering gatekeepers that slow their integration.

\section{Syrian Student Behavior and Mental Health}

On a Government of Canada 2017 webpage with the key lessons learned from the Syrian resettlement initiative, there is agreement that insufficient information was provided to stakeholders regarding the specialized care that government-sponsored refugees would require because of the trauma they had experienced before arrival.

In our survey one of the most frequent topics that emerged from educators' open-ended responses was the high number of students who had experienced trauma before their arrival in Canada and the challenges this posed for teaching and learning. Here is a sampling of perspectives:

Syrian students bring this anger to school leading them to have explosive emotional outbursts and breakdowns.

Students who are dealing with some past trauma cannot learn fully because their negative emotions block their learning.

Syrian students don't seem to understand the value of an education. They don't respect authority. The student I work with gets very angry, defiant and is non-compliant when asked to do something he is supposed to do, like sit on the carpet or listen to the lesson/story etc. He enjoys one-on-one interactions with the teacher, but as soon as he is sent to try and work independently while I work with others, he becomes very disruptive and often does not complete any work.

The first two excerpts suggest that these educators have made a connection between Syrian students' behavior at school and their traumatic experiences prior to coming to Canada. The third comment reflects the views of several of the teachers surveyed and/or interviewed who react quite negatively to the behaviors and attitudes of their Syrian students without connecting these to the trauma they and their families lived.

A teacher from a more rural area shared her concern about the uneven provision of services for refugee families and seems to connect the lack of services in Arabic to parents' perspectives on their daughter's self-harming.

There is a lack of mental health support. So none of my students see the child and youth counsellor in their school even though to my mind many of them have a background of trauma. But the schools just say 'oh well the CYC (child youth counselor) is busy, oh well the CYC doesn't speak Arabic' which to me is unfair because if they were Canadian students who had seen a sibling die or killed, they would be eligible for some counselling.... I had a student self-harming, and there was no support of any kind. In part because the school felt there weren't supports available and in part because we couldn't 
successfully convince the parents that there was an issue. But I think had we been in a more urban area, they would have been able to go talk to people at the settlement centre who might have connected them to a doctor or a therapist or a psychologist who spoke Arabic. But because that wasn't available, there just wasn't anything.

A settlement worker shared examples of two Syrian students who exhibited an awareness of the connection of what their teachers view as problematic behavior and the trauma they have suffered in Syria and/or in refugee camps.

It was so amazing to see an 8-year old who was able to integrate so well and understand his emotions. That's because of the amount of trauma he experienced, it's almost like he had to make sense of things that even an adult couldn't make sense of. He spoke of internal strength that he got from Syria. And he could articulate that he gets angry because he is actually sad.

She (a Syrian student) used to get in trouble a lot, but then I (settlement worker) got involved and we wrote a letter together (for the principal) and she could write her perspective and then the principal finally has a starting conversation. In the refugee camp she said "it was always the survival of the toughest and here I need to use my words instead of my hands, but how do I use my words if I don't know them".

The interview excerpts from a teacher and a settlement worker reflect the key role of communication in the journey of healing and learning. As most educators do not have any knowledge of Arabic and the Syrian students and families are struggling to learn English, there are multiple situations where communication breaks down and important mental health needs go unmet or are misunderstood as problematic behavior that may need to be corrected.

The Hamilton Youth Study (Georgiades et al., 2018) carried out from 2010 to 2013 documents the unmet mental health needs of youth living in immigrant families. Eighty-five percent of the immigrant youth with emotional needs were not able to access services, and $60 \%$ of them with behavioral needs also unable to access the support they need. This is in contrast to $48 \%$ percent of youth born in Canada with emotional needs and $41 \%$ with behavioral needs who were also unable to access support services to meet their needs. According to the lead researcher, Georgiades (CBC News Hamilton, 2013), this study is important for Hamilton and similar cities with high levels of immigration. In Hamilton, immigrants under the age of 15 make up $22 \%$ of the school-age population. In addition, $20 \%$ of Hamilton's newcomer population arrived as refugees which is significantly higher than the national average of about $11 \%$ in 2013.

It would appear that not very much has changed since 2013 when the Hamilton Youth Study data was collected, as the Immigration, Refugees and Citizenship Canada website (2017b) highlights that Syrian refugees who have experienced trauma often require specialized care and that it is essential that service providers including schools and sponsors work to ensure that refugees are able to access the care and services they need to help them integrate. Our data reveals how teachers who do not understand the effects of trauma can become gatekeepers by exhibiting frustration at refugee learners' behavior, while other teachers and settlement workers who understand how to create a trauma sensitive learning environment (see traumasensitiveschools.org) become brokers who provide access to the world of learning and integration. 
Educator Perspectives on the Social and Academic Integration of Syrian Refugees

\section{Multiple Factors Impacting the Educational Integration of Refugee Youth}

Although mental health is an important issue that educators must address to ensure the success of their refugee students, several respondents shared their opinions regarding the factors that impact the social and academic integration of Syrian children and youth. In fact, their stories show us the diversity among the population of Syrian students across schools and regions.

The handful of Syrian students who have strong support systems at home and in the community have really excelled academically, integrated with the other students and are involved in extracurricular activities. However, there are others who are struggling with integration, academics and dealing with authority.

I don't want to paint all my Syrian students with the same brush. I have Syrian newcomers who are learning basic foundational academic skills as a result of not being in school for 6 years while other students are experiencing a great deal of success with near to grade-level math etc. In my former school (2016), we seemed to have a group of students who had more education and therefore had some literacy in Arabic to draw on. Many (29 Syrian children in Grades 4 to 8) in my current school have limited skills compared to the students from last year, and so the academic integration is more challenging. However, they have presented simple projects in their homerooms and are enjoying reading books to their peers about states of matter in Arabic and some of the Grade 8 students are visiting primary classes to share story time in Arabic. It is absolutely essential to set a high bar for our students to reach, as they can reach it!

The Syrian family I work with was privately sponsored and has had a lot of support in their settlement in Canada. The children have been here approximately 15 months and are able to be almost completely independent in the classroom, requiring minimal support. When they first arrived in Canada, they were very anxious to come to school as the two older boys had been out of school for about 2 years and the youngest brother had never attended school. Their parents put a high value on their education and tutored them after they fled Syria. They family has made many friends and have become fully immersed in school and the community.

The Syrian students all have experienced different journeys; for example, although some spent extended periods of time in refugee camps and missed schooling, others were urban refugees and had money to attend school. These different migration experiences impact the integration of refugees once they reside in Ontario.

The settlement workers mentioned how the density of Syrian families in one neighborhood or cluster of apartment buildings can combine with long standing family or ethnically-based feuds to create a difficult atmosphere for Syrian children and youth who want to integrate socially as well as academically. One settlement worker explained that this demands that the Syrian students always be "on edge." Another settlement worker said: "I am seeing two different things. With social integration I see the primary difficulty is with the older ones. When they are older there is that ego piece and the past experiences." However, all the educators surveyed or interviewed agreed that limited knowledge of English restricts the amount and quality of interaction between Syrians and their host communities. In fact, one settlement worker pointed out the power of linguistic knowledge as "language allows us to problem solve." 
Several respondents also highlighted the impact of the type of sponsorship of Syrian families on day-to-day activities. One settlement worker described how refugees who were sponsored by Canadian families or groups of concerned Canadians had an edge over refugee families who were dependent on the government to meet their needs during their first year in Canada:

Academically, we have private sponsors who actually sit and help with homework, and go with the parents to school and help them with forms, and with government sponsored refugees, I have parents that bring forms for five kids and I have to help them with the forms. Even permission forms for field trips.

Another settlement worker explained that her advocacy and support for government sponsored refugees went far beyond their children's integration into Canadian schools and included aspects of daily living: "Things like how the medical system works, or how the banking system works. These are the things that stood out the most for me. I didn't know how bad it was until I had to advocate for them (the Syrian families)." One educator observed how the different types of sponsorship of refugees had created an "unintended two-tiered system".

These varied excerpts from the interviews and survey of educators seem to suggest that the respondents have a more sophisticated understanding of the various factors that make it more or less possible for Syrian students to navigate across their multiple worlds and be successful on the pathway through the education system. Educators seem to understand that intersecting factors such as sponsorship status, SES, gender, language, prior educational background, amount of time since arrival in host country may influence how students are affected by specific educational programming, policies, and practices currently in place for Syrian refugee learners and families. This is reassuring as school-based educators play such a significant role in the educational integration of refugee learners.

\section{Lack of Teacher Preparation and Support for Teachers}

A common concern among educators and curriculum leaders in our study was a lack of teacher preparation and ongoing supports for teachers working with Syrian refugees. One classroom teacher explains: "my Syrian students are all suffering some degree of post-traumatic stress disorder and I feel powerless." Several respondents who are specialist ESL teachers or curriculum leaders describe the varied responses of classroom teachers to their Syrian students while highlighting the need for training and support.

Staff have felt powerless, stressed and fatigued during these past couple of years. We have not been trained or supported in helping the Syrian youngsters or their families.

School staff are trying to engage students. They are still learning how to modify middleschool programs to accommodate students who can't yet read or write. Staff would also benefit from opportunities to learn about how trauma impacts learning.

My students from Syria are very grateful and happy to be in school in Canada. Many of my students have past traumatic experiences, and some (particularly boys) are having difficulty adhering to rules and expectations at school. LEAP (the Literacy Enrichment Academic Program for 11 to 18 year old students who did not have the opportunity to attend school regularly before arriving in Canada) is new to my school this year, and staff have minimal training in recognizing and responding to symptoms of trauma. Students are often considered rude and unruly. 
Educator Perspectives on the Social and Academic Integration of Syrian Refugees

The settlement workers who understand themselves as "two-way cultural brokers" perceived a significant need for teacher development related to intercultural communication and anti-discriminatory education. They reported hearing teachers expressing thoughts such as: "These kids need to learn how to be Canadian. They have to adjust to us!" and "What do they (the Syrians and Arabs) do with their girl?" In fact, one settlement worker reported that in her school community there is "a lot of straight up racism and the children can feel it."

In 2013, Ontario became the first Canadian province to amend its teacher education policy by requiring all teacher candidates to receive curricular and practical experience related to English learners (Accreditation of Teacher Education Programs, 2013). Due to the timeline for the implementation of the policy, it is only in 2016 that most faculties of education rolled out a new course or module on supporting English learners. This new policy has presented both challenges and opportunities for Ontario teacher educators. The main challenge is the "flattening" effect, which involves treating a diverse population such as English learners as though they comprise a homogeneous group. In a 12-18 hour module or a 36-hour course it can be difficult to make space for teacher candidates to understand English learners simultaneously as expert speakers of other languages and complex learners with an emergent bilingual status intersecting with their other identity markers rooted in gender, race, dis/ability, immigration status, and class (Valdés \& Castellón, 2011). However, having both a stand-alone course as well as a program that considers the education of diverse learners across the teacher education curriculum can also create opportunities for teacher candidates to question their assumptions about English learners and the role/place of these students at school, and in society.

Although the initial teacher education policy specifies the need for all teachers to learn to support English learners, there is no such requirement for the professional development of practicing teachers. As such, it is clear that there is a pressing need to provide in-service training. Markus (Gagné, Schmidt, \& Markus, 2017) describes her experiences working with different teacher groups to promote resiliency and language learning among war affected and refugee children and youth in the Toronto School District where there are a large number of refugee students.

As teachers are expected to play an advocacy role in the lives of their Syrian students, we must plan for robust pre-service and in-service teacher education highlighting the various factors that can impact on their Syrian students journey through the school system and across their multiple worlds. Recently, Lam (2017) developed a board game called Refugee JourneysIdentity, Intersectionality and Integration that invites players to recognize that the journey of refugees does not end with their arrival in Canada. This experiential educational tool explores various topics including belonging, identity, discrimination, and culture and allows players to discover the diverse experiences of every refugee and helps teachers to understand that there is so much more to the integration of refugees than learning English.

\section{Relationship with Peers}

Fifty-four percent of the educators report that the Syrian students in their care have begun to develop friendships and engage in conversations with students who are not English language learners. Thirty-six percent of respondents say the Syrian students sit by themselves at lunch or during school assemblies, and $27 \%$ report that Syrian students have begun to get involved in extracurricular activities at the school. Only $36 \%$ of educators state that Syrian students receive sufficient support from other students in their school while 64\% report that their Syrian students receive support from their Arabic-speaking peers. 
The perspective of educators on Syrian students' relationships with other students differ to a certain degree and reveal that having peers who can speak the same language can be a help or a hindrance depending on the context.

I have never in my experience had a group of students that have been so divisive and violent amongst themselves and not made any attempt to integrate or get to know other students of different cultures.

I think it is an enormous mistake to have the Syrian students put together in one classroom. In the 2 years of teaching them I have found that when they are separated and put in classes with other students not of Syrian descent, the severe social problems that they were experiencing, are greatly diminished. All of my Syrian students display this, there is not just one case or exception to this reality.

They prefer to be together only with their own friends in the school. Yes, this is their right and there is nothing wrong about being together with their friends who talk the same native language. However, the fact that they ignore the culture, language and lifestyle of the country they live in and that they live almost as a tribe adversely affects the way we look at each other.

Sometimes, Syrian students are left out when working in groups. They don't participate but usually Syrian students are not included in the conversation and decisions about assigned academic tasks. Part of this is their lack of English but a large part is attributed to not asking/inviting/including Syrian refugees.

In the first year in a new school, when students who do not speak English have peers who speak their own first language, these bilingual students can act as ambassadors who introduce the newcomers to their new environment and explain the various expectations of the school or the classroom. These students who are fluent in both English and in the newcomers' language, can act as bridges to curricular content as well by translating or explaining content and tasks to the English learners. To ensure that this important human resource is in place when possible, formal and/or informal training should be provided so these ambassadors can learn a few basic strategies to support their newly arrived peers. It is also important to spend time with all students so they can understand their role in supporting the integration of their peers who may be refugees or immigrants. Ultimately, we want every person a refugee child interacts with to be a positive force rather than a gatekeeper making the integration journey perilous.

\section{Relationships with Settlement Workers and Social Workers}

Several educators mentioned the positive impact of settlement workers in the integration of the refugee students they work with. In fact, this is the only group that were consistently viewed as advocates for Syrian students helping them navigate between their worlds but, in particular, their pathway in school.

The Settlement Workers in Schools (SWIS) Program is funded by Immigration, Refugees and Citizenship Canada (IRCC) and places settlement workers from community agencies in schools with a large number of immigrant and refugee students. In Ontario, approximately 200 settlement workers from 20 different settlement agencies are based in schools in over 20 school boards across the province (Settlement AtWork Wiki, 2017). According the Settlement AtWork Wiki (2017) the SWIS worker: 
Educator Perspectives on the Social and Academic Integration of Syrian Refugees

- proactively contacts newcomer parents and students to assist them with their settlement needs

- refers the families to more specialized community resources as needed

- provides group information sessions for newcomer youth and parents, often in partnership with school staff

- provides orientation about the settlement needs of newcomers for school staff

- coordinates the Newcomer Orientation Week (NOW) and Welcome and Information for Newcomers (WIN) programs, which take place in the last weeks of the summer in most schools

These excerpts from educators describe some of the many contributions made by the settlement workers in their schools and these reflect the list of job responsibilities listed on the Settlement AtWork Wiki:

One of my students had a difficult time adjusting to school in Canada and she missed her life in Syria. This Grade 8 student saw our social worker for help in dealing with traumatic memories and having no friends in Canada.

Teachers don't always have time to address individual needs so having the settlement worker to communicate the needs and possible strategies discussed with the student to the teacher is valuable.

I have worked closely with the youth settlement worker in our board. She is Arabic speaking. She acts as a liaison and cultural broker to help in bridging the understanding between school and family. I have called upon her expertise for translating purposes, to shed light on cultural information and to connect families to community services. She has been present with me at a number of school meetings with the families. Her support has been extremely valuable.

The guidance Counsellor is working on restorative practices with Syrian students. It's creating opportunities for them to share their stories and begin to heal. They are really enjoying working with him.

Home visits by settlement workers have been particularly successful for families as it allows time for the settlement worker to interact with the family and to address practical needs.

A settlement worker described the challenge of being caught between the divergent worldviews of her clients who are the Syrian refugee families with children in local Canadian schools and the school administrators and teachers:

In reality the best practices are based on western research. And it's not applicable to this population and I needed to be so flexible to convince everyone around me that this will not work with this specific population.

The settlement worker described being chastised by her employer because she frequently accepted to share food brought by family members as they talked through a question or concern. She explained that this went against policy but that it would be considered offensive to refuse 
Antoinette Gagné et al.

food offered as part of a normal socializing practice for Syrians. The settlement worker also mentioned that she was criticized for not directly presenting and discussing Canadian perspectives and policies on domestic violence with the refugee families. She explained that when she simply presented policies and related sanctions for acts of domestic violence, this led to an abrupt end to communication with her Syrian clients. This settlement worker described her preference to work with other community advocates to discuss such matters in a culturally sensitive manner in larger group sessions using scenarios followed by invitation for private consultations as appropriate.

However, there was general agreement among the educators interviewed and survey that settlement workers played a central role in the integration of Syrian children in schools. In fact, one teacher called for additional social workers to be assigned to schools such that each Syrian family is assigned to one particular social worker who can act as a broker for the family and their children as they navigate the school system. Our findings suggest that, overall educators strongly endorse programs such as SWIS, which bring additional caring adults into the lives of children and youth to help them with their educational integration. There is a strong sense that Syrian families would benefit from advocacy at many different levels.

One respondent referenced the Journey Home Project (Ghonaim, 2017) offered in Arabic by the Muslim Resource Centre in London as an example of something that really seems to be working well. It was designed to help immigrants who are experiencing settlement challenges and lasts for 14 weeks, during which parents and children learn together with practical activities focussed on communication skills, healthy relationships, goal-setting, problem solving, and anger management. The project coordinator explains that the program does not require families to abandon their values or identity, but rather it points to the middle ground where parents and children can derive benefits from both the home and host cultures (Ghonaim, 2017).

As such it seems that settlement workers and social workers in schools and communities are best suited to develop strong relationships with Syrian youth and their families to support their educational integration. They seem to play the role of cultural brokering, which involves linking different cultural groups to enhance communication. Brar-Josan and Yohani (2017) describe the activities of four cultural brokers that facilitate the mental health and adaptation of refugee youth to Canadian schools by easing their cultural integration and sense of belonging, connecting them to settlement services, providing supportive counselling, making referrals to mental health practitioners, educating about mental health, as well as providing contextual information and cultural interpretation.

\section{Families}

In response to a question related to knowledge about their Syrian students' families, educator responses varied based on their school context. For example, one teacher in a rural area explained that he knew almost nothing because of the lack of interpreters, while another teacher from an urban center reported working closely with Syrian families with the help of an interpreter who would make phone calls and personally invite families to school events and interviews. The same teacher explained that with the support of the interpreter, she was able to see how willing parents were to become involved and how deeply they cared about their children's wellbeing and success. Yet another teacher from a suburban school commented that when "large families settle away from the city centres in order to find appropriate housing, they may end up being isolated in the suburbs, without a car and inadequate public transportation to get places." A teacher from a different urban school described how his Syrian students led the parent-teacher conference by explaining to their parents in Arabic how their classroom works and what they are learning by showing samples of their work. 
Educator Perspectives on the Social and Academic Integration of Syrian Refugees

One teacher highlighted the intergenerational trauma she observed among her Syrian students and described how parents' sadness over their multiple losses can easily be passed on to their children.

I believe the Syrian refugee students have suffered tremendously as a result of the war in their country. They are scarred. They are grieving their loss of home, family and identity. I think the sadness and hopelessness of the parents have transferred to the children. As one dad said to me, one day I had a two-story home and two cars out front. The next day, it is all gone and I'm living in a camp, fighting for my safety and my children's safety every day for 3 years. How absolutely horrific!

Finally, two educators in leadership roles commented on the negative views of Syrian families held by some educators or the lack of sensitivity of school personnel to the trauma many families have and continue to experience.

Some teachers I work with feel parents don't care about their children's success, but they don't recognize that parents are dealing with several children, all with social/emotional needs, that parents themselves are dealing with traumatic pasts and culture shock, and that they feel ill-equipped to advocate for their kids.

Parents are constantly called in to pick up their kids for misconduct but there is little consideration for past experiences or trauma and the impact that may have.

In fact, a settlement worker described how one Syrian father had been summoned to the school mid-day because of a safety concern regarding his son: "The school told him there is a safety concern. Do you realize how ridiculous that sounds to someone who escaped war that their son is dangerous because he is running around with scissors?"

Our findings reveal that the way Syrian families are welcomed into schools and perceived by personnel varies greatly which likely influences their views of the school system and how they relate to their children about this important aspect of their life.

\section{Relationships with Teachers and Principals}

We have already discussed the key role of educators, including teachers and principals, in supporting the integration of Syrian children and youth in schools through the lens of the data focused on mental health and other various factors impacting refugee settlement. In this section, we highlight some of the findings from the survey, where $73 \%$ of the respondents either agreed or strongly agreed with the following statement: The Syrian refugee students I work with bring valuable contributions to the classroom learning environment, which suggests that the majority of educators view Syrian students in a positive light. In spite of this, 55\% of the educators agreed that the Syrian refugees at their school had difficult/strained relationships with teachers and school administrators. Surprisingly, 55\% of respondents also agreed that Syrian students receive sufficient support from teachers while 59\% agreed or strongly agreed that Syrian refugees at their school received sufficient support from the administrators. Although these findings seem somewhat contradictory, it is not difficult to imagine why there is divergence among the views and experiences of educators when one considers the very diverse school contexts in which they work with Syrian students. 
Antoinette Gagné et al.

The following excerpts suggest that even within a school which is supportive and sensitive to the needs of Syrian refugees, there may be individual teachers who are not as willing to modify their practices and into account the trauma Syrian students may have experienced.

I think my schools would say the students feel welcome - I myself would wish for more meaningful integration and respect for their ESL needs

It's hard to convince some teachers to modify for ELLs, even ELD intermediate students with a background of trauma.

Not every teacher understands the full situation of these students. Not every teacher understands and is willing to provide modifications to the curriculum in order to reach these students.

The students are sometimes hesitant to approach classroom teachers if they do not understand an assignment.

As teachers and school leaders have such influence on the lives of students, it is important to consider ways to ensure that the relationships between these educators and Syrian students and their families are strengthened to ensure the smooth transition of children across their multiple worlds.

\section{Revisiting the Bridging Multiple Worlds Theory}

Our findings highlight the multiple roles of parents and caregivers, peers, teachers, school administrators and especially settlement workers in the integration of Syrian children and youth in schools. As refugee students navigate through the school system, spend time in community settings and at home, their relationships with peers and other adults including educators can either hinder or enhance their transitions from one world to another.

\section{Implications}

In one workshop focused on the mental health of migrant youth and their families at the 2018 Ontario Education Research Symposium with the theme of "Advancing Equity and Achievement in Ontario Classrooms," the audience was invited to consider next steps in light of the various findings presented by a group of researchers (Georgiades, Ma, Vitoroulis, \& Campo, 2018). Although the topic was mental health, many of the recommendations resonated for us and could easily be next steps for our research study focused on the social and academic integration of Syrian refugees. These included the need to work collaboratively to build strong evidence that documents the social and emotional needs of migrant youth and their families, as well as how to address these needs in Canada through longitudinal studies focusing on transition points in terms of development (e.g., adolescence) and contexts (middle school), and rigorous evaluations of existing and new approaches to facilitate access to mental health services among migrant youth to inform change and enhance practice - all this keeping in mind that schools represent and optimal setting for research as well as preventative interventions.

The Canadian government recognizes the need for programming tailored to meet the needs of Syrian refugee youth (Government of Canada, 2017b) and lists the several programs funded by Immigration, Refugees and Citizenship Canada (IRCC), including summer programming, Arabic-speaking youth workers, and youth employment programs, interactive activities and games to support informal language learning, opportunities to bring together 
participants from various cultural backgrounds to facilitate community integration. IRCC writes about the importance of engaging directly with newcomer youth, who have diverse skills, knowledge and experience.

In addition to the programming initiatives funded by the IRCC, there is a need for schoolbased planning where school communities who welcome refugees consider a series of questions to determine how they can become a trauma sensitive school where the educational impacts of trauma are understood (Trauma Learning Policy Initiative, 2018). It is important to take time for a whole-school discussion to determine the most pressing priorities that can be addressed in the short term to make the school more trauma sensitive. The Trauma Learning Policy Initiative (2018) suggests a series of questions related to possible actions that a school might take to become more trauma sensitive. These questions include:

How will the actions we have decided to take as a school community:

1. deepen our shared understanding of how trauma impacts learning and why a school-wide approach is needed for creating a trauma sensitive school?

2. help the school effectively support all students to feel safe physically, socially, emotionally and academically?

3. address students' needs in holistic ways, taking into account their relationships, self-regulation, academic competence and physical and emotional well-being?

4. explicitly connect students to the school community and provide multiple opportunities for students to practice newly developing skills throughout the school?

5. support staff's capacity to work together as a team with a sense of shared responsibility for every student?

6. help the school anticipate and adapt to the ever-changing needs of our students and the surrounding community?

There are also numerous research-informed resources developed in Canada as well as in other refugee receiving countries that can support the work of school teams and individual teachers in their quest to support refugee learners at school (See the Appendix for a partial list of resources and relevant research). An Alberta-based website called Teaching Refugees with Limited Formal Learning provides some useful trauma-informed tips from teachers with many examples of how the advice might be operationalized in different contexts. These tips from teachers of immigrants and refugee learners for teachers include: 


\begin{tabular}{|c|c|}
\hline Building Connections & $\begin{array}{l}\text { Effective approaches for supporting children with refugee } \\
\text { backgrounds emphasize building, or re-building, safe } \\
\text { relationships. School staff members play a vital role as safe } \\
\text { and caring adults. Building safe connections is foundational to } \\
\text { success in classroom and school. }\end{array}$ \\
\hline Creating Safety \& Routines & $\begin{array}{l}\text { Creating a classroom that feels safe is essential for children } \\
\text { who have experienced trauma. Routines are the easiest way to } \\
\text { communicate safety an offer the opportunity to know what } \\
\text { will happen next. }\end{array}$ \\
\hline $\begin{array}{l}\text { Fostering Emotional Skills } \\
\text { Development }\end{array}$ & $\begin{array}{l}\text { Learning to manage emotions is part of normal development. } \\
\text { Emotional skills are important life skills and classroom- } \\
\text { survival skills. Many behavioral issues in classrooms are the } \\
\text { result of limited emotional skill development. Students whose } \\
\text { normal development has been interrupted may not have had } \\
\text { the chance to learn to manage intense emotions. }\end{array}$ \\
\hline Learning When to Refer & $\begin{array}{l}\text { Teachers are often the first to refer to counselling or } \\
\text { additional support. Teachers are consistent adults who see } \\
\text { students' emotional and mental states over time. Students } \\
\text { from refugee backgrounds are at risk of mental health issues } \\
\text { related to past losses and multiple stressors and trauma. } \\
\text { Acculturation challenges and mental stressors may in fact } \\
\text { increase the needs of refugee children or youth as they settle } \\
\text { in Canada and require individual attention. Typically, } \\
\text { members of the same family will have different levels of } \\
\text { resilience in responding to stressors and traumas. Teachers } \\
\text { can be key to timely interventions. }\end{array}$ \\
\hline
\end{tabular}

Doing Self-Care Working with students with refugee backgrounds exposes teachers and other professionals to very difficult situations and heart-wrenching first-hand stories. This material can be challenging to process, and can erode an adult's fundamental sense of safety and well-being. Self-care is key to remaining healthy in work with students with histories of loss, grief, stress and trauma.

Figure 2. Trauma-informed tips from teachers adapted from the Teaching Refugees with Limited Formal Learning

We must recognize that refugee children and youth face unique experiences of discrimination and that systemic bias, practices and processes in schools often result in differential treatment of these racialized and marginalized children and youth. The role of relationships in the lives of Syrian refugee students in key to their educational integration and their ability to navigate across their multiple worlds with ease. 
Educator Perspectives on the Social and Academic Integration of Syrian Refugees

\section{References}

Accreditation of Teacher Education Programs, O. Reg. 347/02, Schedule 1 (2013). Retrieved from http://www.ontario.ca/laws/regulation/020347.

Allard, E. C. (2016). Latecomers: The sources and impacts of late arrival among adolescent immigrant students. Anthropology \& Education Quarterly, 47(4), 366-384. doi:10.1111/aeq.12166

Brar-Josan, N. and Yohani, S. (2017). Cultural brokers' role in facilitating informal and formal mental health supports for refugee youth in school and community context: a Canadian case study. British Journal of Guidance and Counselling. Doi.10.1080/03069885.2017.1403010

Bronfenbrenner, U. (1979). The ecology of human development: Experiments by nature and design. Cambridge, MA: Harvard University Press.

Bronfenbrenner, U., \& Morris, P. A. (2006). The bioecological model of human development. In R. M. Lerner \& W. Damon (Eds.), Handbook of child psychology: Theoretical models of human development (pp. 793-828). Hoboken, NJ: John Wiley.

Calgary Board of Education \& Government of Alberta - Education. (n.d.). Trauma-informed Tips for Teachers. Retrieved from http://teachingrefugees.com/

Chostelidou, D., \& Griva, E. (2014). Bilingual immigrant children and literacy development: Inclusive learning issues and challenges. International Journal on New Trends in Education and Their Implications, 5(3), 18th ser., 170-180. Retrieved from http://www.ijonte.org/FileUpload/ks63207/File/18.griva.pdf

Cooper C. R. (1994). Cultural perspectives on continuity and change in adolescents' relationships. In R. Montemayor, G. R. Adams, T. P. Gulotta (Eds.) Advances in Adolescent Development. Personal Relationships During Adolescence, 6, (pp. 78-100). Newbury Park, CA: Sage

Cooper, C. R. (2014). Bridging multiple worlds: cultures, identities, and pathways to college. New York: Oxford University Press.

Cooper, C. R. \& Denner, J. (1998). Theories linking culture and psychology: Universal and community-specific processes. Annual Review of Psychology, 49, 559-84

Cummins, J., Hu, S., Markus, P. \& Kristina Montero, M. (2015). Identity texts and academic achievement: Connecting the dots in multilingual school contexts. TESOL Quarterly, 49, 555-581. doi:10.1002/tesq.241

Davy, D. (2013, May 7). Immigrant youth have fewer mental health issues, Hamilton study shows. CBC News. Retrieved from http://www.cbc.ca/news/canada/hamilton/news/immigrant-youth-have-fewer-mental-healthissues-hamilton-study-shows-1.1406369

Gagné, A., Schmidt, C. \& Markus, P. (2017). Teaching about refugees: Developing culturally responsive educators in contexts of politicized transnationalism. Special issue of Intercultural Education on Teaching About Refugees, 28(5). 429-446, DOI: $\underline{10.1080 / 14675986.2017 .1336409}$ 
Georgiades, K., Ma, S., Vitoroulis, I., \& Campo, M. (2018). Inequities in mental health and wellbeing among immigrant and refugee youth: Evidence for action in the education system. Department of Psychiatry and Behavioural Neurosciences, McMaster University \& Offord Centre for Child Studies. Paper presented at the Ontario Education Research Symposium March 1, 2018.

Giampapa, F. (2010). Multiliteracies, pedagogy and identities: Teacher and student voices from a Toronto elementary school. Canadian Journal of Education, 33(2), 407-431. Retrieved from http://myaccess.library.utoronto.ca/login?url=http://search.proquest.com/docview/750360074 ?accountid=14771

Ghonaim, H. (2017, November 26). From bully to best friend: how an Ontario program helped a Syrian refugee figure out his new home. $C B C$ News. Retrieved from http://www.cbc.ca/news/canada/london/journey-home-project-london-1.4417323

Government of Canada. (2017a). WelcomeRefugees: Key figures. Retrieved from https://www.canada.ca/en/immigration-refugees-citizenship/services/refugees/welcomesyrian-refugees/key-figures.html

Government of Canada. (2017b). Syrian Refugee Resettlement Initiative - Looking to the Future. Retrieved from https://www.canada.ca/en/immigration-refugeescitizenship/services/refugees/welcome-syrian-refugees/looking-future.html

Guo, Y. (2012). Diversity in public education: Acknowledging immigrant parent knowledge. Canadian Journal of Education, 35(2), 120-140. Retrieved from http://myaccess.library.utoronto.ca/login?url=http://search.proquest.com/docview/103266197 $\underline{3 \text { ? accountid }=14771}$

Lam, M. (2017). Refugee journeys: Identity, intersectionality, and integration. Madison, WI: Birdlight Games.

Mackinnon, M. (2017, November 12). What distinguishes the Syrians arriving in Canada from those reaching Europe? Retrieved from http://www.theglobeandmail.com/news/world/whatdistinguishes-the-syrians-arriving-in-europe-from-those-incanada/article28614428/

Minichiello, D. (2001). Chinese voices in a Canadian secondary school landscape. Canadian Journal of Education, 26(3). Retrieved from http://myaccess.library.utoronto.ca/login?url=http://search.proquest.com/docview/215376637 ?accountid=14771

Ontario Ministry of Education. (2008). Supporting English language learners with limited prior schooling: A practical guide for Ontario educators (Grades 3 to 12). Retrieved from http://www.edu.gov.on.ca/eng/document/manyroots/ELL_LPS.pdf

Ontario Ministry of Education. (2015). STEP Steps to English Proficiency: A Guide for Users. Retrieved from http://www.edugains.ca/resourcesELL/Assessment/STEP/STEPUserGuide_November2015.p $\underline{\mathrm{df}}$

Refugees from Syria. (2014). Retrieved from http://www.culturalorientation.net/learning/backgrounders 
Educator Perspectives on the Social and Academic Integration of Syrian Refugees

Roxas, K. (2011). Creating communities: Working with refugee students in classrooms. Democracy \& Education, 19(2). Retrieved from http://go.galegroup.com.myaccess.library.utoronto.ca/ps/i.do?p=AONE\&sw=w\&u=utoronto _main\&fv=2.1\&it=r\&id-GALE\%7CA271596123\&sid=summon\&asidh006fa50f0def3a10e00f2fe9d0d8

Sergiovanni, T. (1994). Building community in schools. San Francisco, CA: Jossey-Bass.

Sandals, L. (2015, December 4). Ministry of Education (Canada, The Ministry of Education). Retrieved from http://www.edu.gov.on.ca/eng/policyfunding/memos/dec2015/min_syrianrefugee.pdf

Settlement AtWork Wiki. (2017) Settlement Workers in Schools (SWIS). Retrieved from http://wiki.settlementatwork.org/index.php?title=Settlement_Workers_in_Schools_(SWIS)

Szente, J., Hoot, J., \& Taylor, D. (2006). Responding to the special needs of refugee children: Practical ideas for teachers. Early Childhood Education Journal, 34(1), 15-20. Retrieved from http://myaccess.library.utoronto.ca/login?url=https://search-proquestcom.myaccess.library.utoronto.ca/docview/62114299?accountid=14771

Taylor, S., \& Sidhu, R. K. (2012). Supporting refugee students in schools: What constitutes inclusive education? International Journal of Inclusive Education, 16(1), 39-56. doi:10.1080/13603110903560085

Toronto District School Board. (n.d.). English as a Second Language/English Literacy Development LEAP (Literacy Enrichment Academic Program). Retrieved from http://www.tdsb.on.ca/High-School/Your-School-Day/English-as-a-Second-Language

Trauma Learning Policy Initiative. (2018, January 18). Creating a Successful Action Plan (Part 1). Retrieved from https://traumasensitiveschools.org/creating-successful-action-plan-part-1/

Valdés, G., \& Castellón, M. (2011). English language learners in American schools: Characteristics and challenges. In T. Lucas (Ed.), Teacher preparation for linguistically diverse classrooms: A resource for teacher educators (pp. 18-34). New York: Routledge.

Zegarac, G. (2015, December 4). Syrian Refugee Resettlement in Ontario, Ontario Ministry of Education. Retrieved from http://www.msdsb.net/images/ADMIN/correspondence/2015/DM_Syrian_Refugee_Settleme nt_in_Ontario.pdf

Zegarac, G. (2016, March 2). Syrian Refugee Resettlement in Ontario, Ontario Ministry of Education. Retrieved from http://www.edu.gov.on.ca/eng/policyfunding/memos/march2016/on_syrian_newcomer.pdf 


\section{Appendix}

\section{Additional Resources to Support Educators Working with Refugee Children and Youth}

Calgary Board of Education. (2015). Complex English language learners: A tool to support school learning teams. Downlaoded from http://teachingrefugees.com/wpcontent/uploads/2015/02/CELLS- February-2015.pdf.

Cranitch, M. (2010). Developing language and literacy skills to support refugee students in the transition from primary to secondary school. Australian Journal of Language and Literacy, 33(3). 255-267.

Crul, M. (2017). Refugee children in education in Europe. How to prevent a lost generation? SIRIUS Network Policy Brief Series, Issue 7, February 2017.

Dachyshyn, D., \& Kirova, A. (2011). Classroom challenges in developing an intercultural early learning program for refugee children. Alberta Journal of Educational Research, 57(2), 220233.

Geres, K. (2010). Using digital narratives with refugee and immigrant youth to promote literacy, healing, and hope. Dr. Stirling McDowell Foundation for Research into Teaching.

Herzog-Punzenberger, B., Le Pichon, E., \& Siarova, H. (2017). Multilingual education in the light of diversity: Lessons learned. NESET II report, Luxembourg: Publications Office of the European Union, 2017. doi: 10.2766/71255.

Islamic Social Services Association \& National Council of Canadian Muslims. (2014). Helping Students Deal with Trauma Related to Geopolitical Violence and Islamaphobia. Retrieved from https://www.nccm.ca/wp-content/uploads/2016/08/ED-GUIDE-ENGLISH-BOOK.pdf

Kanu, Y. (2008). Educational needs and barriers for African refugee students in Manitoba. Canadian Journal of Education, 31(4), 915-939.

MacNevin, J. (2012). Learning the way: Teaching and learning with and for youth from refugee backgrounds on Prince Edward Island. Canadian Journal of Education, 35(3), 48-63.

Manitoba Education and Advanced Learning. (2015). Building hope: Refugee learner narratives. Winnipeg, MB: Manitoba Education and Advanced Learning. Downloaded from: http://www.edu.gov.mb.ca/k12/docs/support/building_hope/index.html.

Manitoba Education. (2012). War-affected children: A comprehensive bibliography. Winnipeg, MB. Downloaded from http://www.edu.gov.mb.ca/k12/docs/support/law/bibliography.pdf.

Miller, J., Windle, J. A., \& Yazdanpanah, L. K. (2014). Planning lessons for refugee-background students: Challenges and strategies. International Journal of Pedagogies \& Learning, 9(1), $38-48$.

Sirin, S.R., \& Rogers-Sirin, L. (2015). The educational and mental health needs of Syrian refugee children. Washington, DC: Migration Policy Institute. Downloaded from http://www.migrationpolicy.org/research/educational-and-mental-health-needs-syrianrefugee-children. 
Educator Perspectives on the Social and Academic Integration of Syrian Refugees

Stewart, J. (2012). Transforming schools and strengthening leadership to support the educational and psychosocial needs of war-affected children living in Canada. Diaspora, Indigenous, and Minority Education, 6(3), 172-189.

Tyrer, R.A., \& Fazel, M. (2014). School and community-based interventions for refugee and asylum seeking children: A systematic review. PLoS One 9(2): e89359. Downloaded from http://journals.plos.org/plosone/article/asset?id=10.1371\%2Fjournal.pone. 0089359.PDF.

Victoria Department of Education and Training. (n.d.). Schools and families in partnership: A desktop guide to engaging families from refugee backgrounds in their children's learning. Downloaded from http://www.foundationhouse.org.au/schools-and-families-in-partnership-adesktop-guide-to-engaging- families-from-refugee-backgrounds-in-their-childrens-learning/.

Windle, J., \& Miller, J. (2012). Approaches to teaching low literacy refugee-background students. Australian Journal of Language and Literacy, 35(3), 317-333.

Woods, A. (2009). Learning to be literate: Issues of pedagogy for recently arrived refugee youth in Australia. Critical Inquiry in Language Studies, 6(2), 81-101.

Yohani, S. (2013). Educational cultural brokers and the school adaptation of refugee children and families: Challenges and opportunities. Journal of International Migration and Integration, 14(1), 61 .

Young, M., \& Chan, K. J. (2014). School-based interventions for refugee children and youth. In C. A. Brewer \& M. McCabe (Eds.), Immigrant and refugee students in Canada (pp. 31-53). Alberta: Brush Education, Inc. 
Antoinette Gagné et al.

\section{Background Information}

Al-Qazzaz Foundation for Education and Development. (n.d.). QED Projects. Retrieved from http://q-ed.org/qed-projects/

Brewer, C. A. \& McCabe, M. (Eds.) (2014). Immigrant and refugee students in Canada. Alberta, Canada: Brush Education Inc.

Calgary Board of Education (2015). Complex English Language Learners (CELLS): A tool to Support School Learning Teams. Retrieved from http://teachingrefugees.com/wpcontent/uploads/2015/02/CELLS-February-2015.pdf

Chignall, S. (2016, April 25). Children of refugees thrive in Canada: StatsCan study. Retrieved from http://ipolitics.ca/2016/04/25/children-of-refugees-thrive-in-canada-statscan-study/

Islamic Social Services Association \& National Council of Canadian Muslims. (2014). Helping students deal with trauma related to geopolitical violence and Islamaphobia. Retrieved from https://www.nccm.ca/wp-content/uploads/2016/08/ED-GUIDE-ENGLISH-BOOK.pdf

Melzak, S. (2014). Reading and expressive writing with traumatised children, youth refugees and asylum seekers. Marion Baraitser: Great Britain.

Nelson, C., \& Appleby, R. (2015). Conflict, militarization and their after-effects: Key challenges for TESOL. TESOL Quarterly, 49, 309-332.

OECD. (2015) Helping immigrant students to succeed at school-and beyond. Retrieved from https://www.oecd.org/education/Helping-immigrant-students-to-succeed-at-school-andbeyond.pdf

\section{Mental Health}

British Columbia Ministry of Education. (2009). Students from refugee backgrounds: A guide for teachers and schools. Victoria, BC: Queen's printer for British Columbia. Retrieved from http://www2.gov.bc.ca/gov/content/education-training/administration/kindergarten-to-grade12/refugee-students

Boston Children's Hospital Centre for Refugee Trauma and Resilience. (2012). Trauma Toolkit. Retrieved from https://learn.nctsn.org/enrol/index.php?id=62

School Mental Health Assist (2016). Info-sheet: Welcoming Syrian newcomer students \& families to school. Retrieved from http://www.edugains.ca/resourcesMH/Classroom Educator/AdditionalResources/InfoSheet_Newcomers.pdf

Sirin, S. \& Rogers-Sirin, L. (2015). The educational and mental health needs of Syrian refugees. Washington DC: Migration Policy Institute.

Victoria Foundation for Survivors of Torture Inc. (2004). Schools in for refugees: Whole-school guide to refugee readiness. Retrieved from http://www.goodrunsolutions.com.au/ resources/downloads/links/PDF_REFUGEES_-_Guide_to_school_rediness.pdf

Ziegler, D. (n.d.) Optimum learning environments for traumatized children: How abused children learn best in school. Retrieved from http://www.jaspermountain.org/optimum_learning_environment.pdf

\section{Guides for Teachers}


Educator Perspectives on the Social and Academic Integration of Syrian Refugees

CMAS. (2018). The resilience guide: Program strategies for responding to trauma in refugee children. Toronto, ON: CMAS. Retrieved from https://cmascanada.ca/wpcontent/uploads/2018/02/resilienceguide.pdf

CMAS. (2015). Caring for Syrian refugee children: A program guide for welcoming young children and their families. Toronto, ON: CMAS. Retrieved from https://cmascanada.ca//wpcontent/uploads/2015/12/Supporting_Refugees/Caring\%20for\%20Syrian\%20Refugee\%20Ch ildren-final.pdf

Chumak-Horbatsch, R. (2012). Linguistically appropriate practice: A guide for working with young immigrant children. Toronto: University of Toronto Press.

DeCapua, A., \& Marshall, H. W. (2011). Breaking new ground: Teaching students with limited or interrupted formal education in U.S. secondary schools. Ann Arbor, MI: University of Michigan Press.

Manitoba Education and Advanced Learning (2015). Life after war: Education as a healing process for refugee and war affected children. Retrieved from http://www.edu.gov.mb.ca/k12/docs/support/law/law_interactive.pdf

Ontario Ministry of Education. (2008). Supporting English language learners with limited prior schooling. Capacity Building Series. Retrieved from http://www.edu.gov.on.ca/eng/document/manyroots/ELL_LPS.pdf

Ontario Ministry of Education. (2014). English literacy development supporting English language learners with limited prior schooling. Retrieved from http://www.edu.gov.on.ca/eng/literacy numeracy/inspire/research/CBS_LiteracyDevelop.pdf

Ontario Ministry of Education. (2016). Supporting students with refugee backgrounds: A framework for responsive practice. Capacity Building Series. Retrieved from http://thelearningexchange.ca/wp-content/uploads/2017/02/cbs_refugees.pdf

Robertson, K. \& Breiseth, L. (n.d.). How to support refugee students in the ELL classroom Retrieved from http://www.colorincolorado.org/article/how-support-refugee-students-ell$\underline{\text { classroom }}$

\section{Programs}

Howells, L. (2016, November 06). Syrians and Canadians trade languages at weekly U of T workshop. Retrieved from http://www.cbc.ca/news/canada/toronto/syrian-university-oftoronto-languages-1.3838658

Ngabo, G. (2016, October 14). Toronto Syrians launching English tutorials for refugees stuck on ESL waiting list | Metro Toronto. Retrieved from http://www.metronews.ca/news/ toronto/2016/10/14/syrians-launching-english-tutorials-for-refugees.html

Slane, A. (2014, January). The Peaceful Village: Supporting newcomer students and their families. Retrieved from http://www.cea-ace.ca/education-canada/article/peaceful-village

Silverman, R. (2015, September 21). Refugee kids: One small school takes on the world. Trailer. Retrieved from https://vimeo.com/139950532 
Antoinette Gagné et al.

Trainor, S. (2016, July 04). Syrian students continue language learning through summer camps. Retrieved from http://www.cbc.ca/news/canada/new-brunswick/saint-john-language-campssyrian-students-1.3663381 